\title{
Effects of multisensory stimulation with virtual reality therapy on psychological parameters in patients with stroke
}

\author{
Lavinia Raluca Butuc, Liviu Lazar \\ Faculty of Medicine and Pharmacy, University of Oradea, Oradea, Romania
}

\begin{abstract}
This article presents a systematic analysis with the intention of showcasing the effects of the multi-sensory stimulation therapy with virtual reality on psychological parameters in patients with stroke. The main objective of this study was to determine the effectiveness of this multisensory therapy on the patient's psyche, especially the impact on cognitive function, as well as the impact on daily activities and the assessment of possible negative influences.
\end{abstract}

Keywords: multi-sensory stimulation therapy with virtual reality, medical recovery, software, plegia, virtual games, virtual environments

\section{INTRODUCTION}

In the last decade, the number of patients who have suffered strokes or traumatic injuries has increased considerably. A series of studies have shown that medical recovery based on repetitive movements, focused mainly on carrying out different tasks is effective in the improvement of movement abilities (1). Stroke is often accompanied by anxiety and depression in patients. Frequently, patients diagnosed with stroke tend to conceal subtle thoughts and feelings, often hiding them from their doctors, for fear of being subjected to common depression-related prejudices (2). Multisensory stimulation with virtual reality therapy is defined as a virtual, immersive and three-dimensional environment which occurs in real time and stimulates even patients with physical and cognitive disability into active participation (3).

\section{MATERIAL AND METHOD}

To determine the degree of anxiety and depression present following stroke we applied the fol- lowing assessment scales: Geriatric Depression Scale (GDS), Hamilton Anxiety Rating Scale (HAM-A) and Beck Anxiety Inventory (BAI). The questionnaires focused on the evolution of depression and anxiety, physical activity and psychological support. We conducted a prospective randomized study involving two homogeneous lots of patients with stroke, namely: a study group consisting of 30 patients who underwent physiokinetic therapy and multisensory stimulation therapy with virtual reality, and the control group in which there were 36 of patients under physiokinetic therapy but without multisensory stimulation therapy with virtual reality (Figure 1 and Table 1).

TABLE 1. The distribution by gender

\begin{tabular}{|l|l|l|l|l|}
\hline \multirow{2}{*}{ Gender } & \multicolumn{2}{|l|}{ Study group } & \multicolumn{2}{l|}{ Control group } \\
\cline { 2 - 5 } & No. & $\%$ & No. & $\%$ \\
\hline Female & 11 & 36.67 & 12 & 33.33 \\
\hline Male & 19 & 63.33 & 24 & 66.67 \\
\hline Total & $\mathbf{3 0}$ & $\mathbf{1 0 0 . 0 0}$ & $\mathbf{3 6}$ & $\mathbf{1 0 0 . 0}$ \\
\hline
\end{tabular}

Men prevailed in both groups, the male / female ratio being 1.7: 1 in the study group, respectively 2 : 


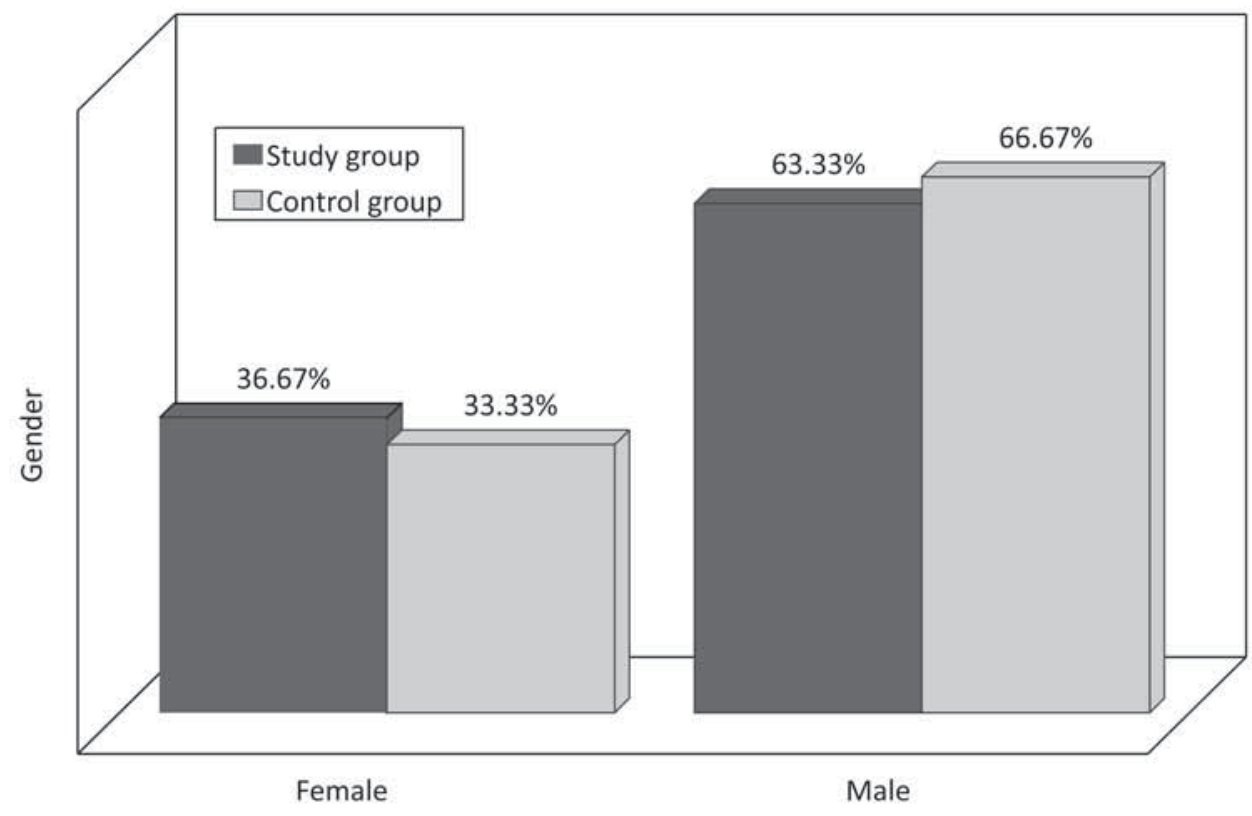

FIGURE 1. The distribution by gender
1 in the control group. There are no significant differences between the two groups in terms of sex distribution $(\mathrm{p}=0.7784)$ (Table 1$)$.

In the study groups the majority of patients were over 50 years old $(73.33 \%$ and $80.56 \%$ respectively), without significant differences between the two groups $(p=0.126)$ (Figure 2).

TABLE 2. The distribution by age

\begin{tabular}{|l|c|c|c|c|}
\hline \multirow{2}{*}{ Age } & \multicolumn{2}{|c|}{ Study group } & \multicolumn{2}{c|}{ Control group } \\
\cline { 2 - 5 } & No. & $\%$ & No. & $\%$ \\
\hline $\mathrm{f} 40$ years & 3 & 10.00 & 1 & 2.78 \\
\hline $41-50$ years & 5 & 16.67 & 6 & 16.67 \\
\hline $51-60$ years & 10 & 33.33 & 11 & 30.56 \\
\hline$>60$ years & 12 & 40.00 & 18 & 50.00 \\
\hline
\end{tabular}

TABLE 3. The distribution by type of stroke

\begin{tabular}{|l|c|c|c|c|}
\hline \multirow{2}{*}{ Type of stroke } & \multicolumn{2}{|c|}{ Study group } & \multicolumn{2}{c|}{ Control group } \\
\cline { 2 - 5 } & No. & $\%$ & No. & $\%$ \\
\hline Hemorrhagic & 13 & 43.33 & 16 & 44.44 \\
\hline Ischemic & 17 & 56.67 & 20 & 55.56 \\
\hline
\end{tabular}

Figure 3 and Table 3 show that over $55 \%$ of the patients in both groups suffered from stroke ischemic $(56.67 \%$ and $55.56 \%$ respectively) $(\mathrm{p}=0.9285)$.

The inclusion criteria were as follows: patients with ischemic and hemorrhagic stroke aged between 24 and 75 years; the time span of the vascular event being: I: between 3 and 6 months; II: between 6 months -1 year and III: over one

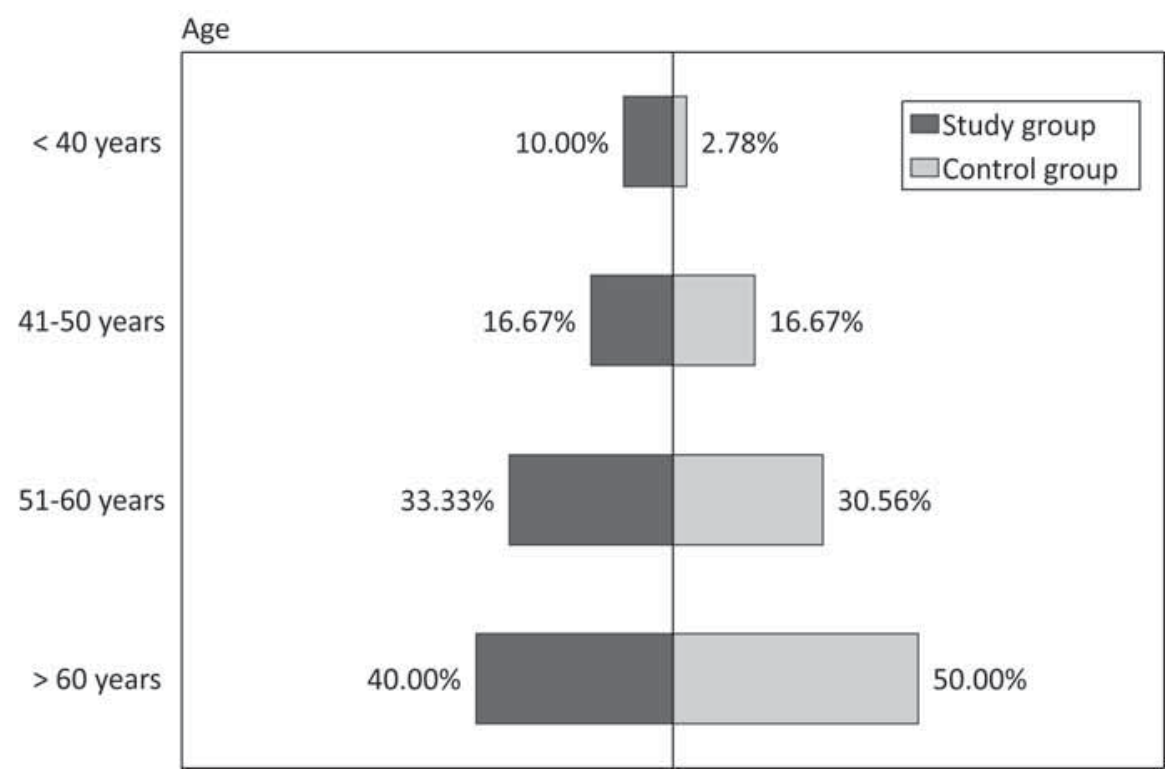

FIGURE 2. The distribution by age 


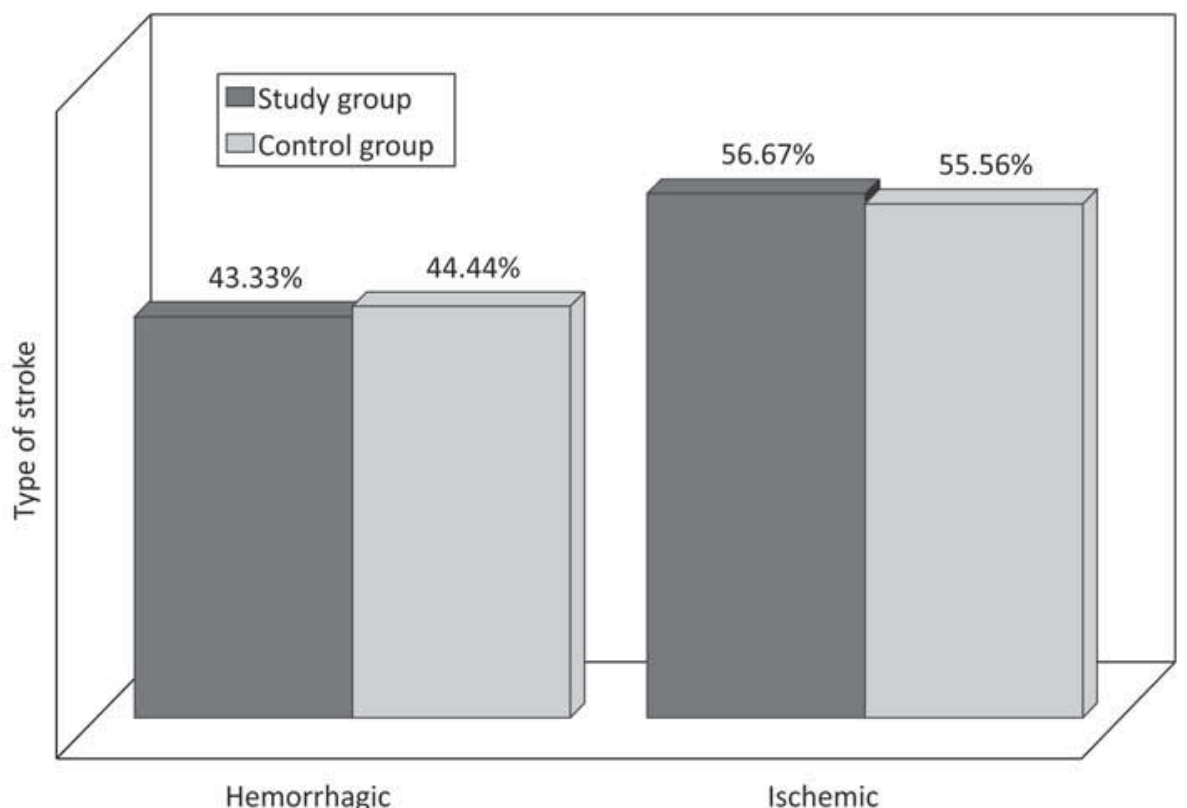

FIGURE 3. The distribution by type of stroke year; patients with stroke that is confirmed by clinical examinations and paraclinical investigations and patients who have expressed a desire to be treated with multisensory stimulation therapy with virtual reality and gait testing and the exclusion criteria were: patients less than 24 years old and older than 75 years; patients with visual and hearing impairments who could not interact with multisensory virtual reality therapy and gait testing; patients with mental illness.

All patients were informed about the study and gave their consent by signing the informed consent form.

The study was conducted in the Băile Felix Medical Recovery Hospital from November 2016 to August 2017. Patients were assessed when they were included in the study and after 6 months.

\section{RESULTS AND DISCUSSION}

The results regarding the patients' perception of depression are shown in Table 4 and Figure 4, as follows:
As can be seen initially, the degree of geriatric depression has had normal outcomes for $30.00 \%$ of the patients in the study group, respectively $27.78 \%$ in the control group $(\mathrm{p}=0.8440)$ and severe depression for $10.00 \%$ and $13.89 \%$ of the patients, respectively $(p=0.6323)$. After 6 months the degree of geriatric depression has had a normal result at $70.00 \%$ of the patients in the study group, respectively $47.22 \%$ in the control group $(p=0.0643)$ and severe depression at $6.67 \%$ in the study group, respectively $11.11 \%$ of the patients in the control group $(\mathrm{p}=0.5353)$.

The mean GDS score in the Study group decreased within 6 months from 12.83 to 8.90 ( $\mathrm{p}=$ 0.0037 ) and in the Control group from 13.39 to 12.03 $(p=0.1525)$. Thus the treatment effect on geriatric depression was 3 times higher in the Study group than in the Control group ( $\mathrm{ES}=0.78, \mathrm{ES}=0.26$ ).

Although the presence of depression may go unnoticed, this is the most common psychiatric disorder present in elderly patients, thus being one of the main grounds in medical examination (Blazer, 2003) (4).

TABLE 4. Evolution of geriatric depression - Geriatric Depression Scale (GDS)

\begin{tabular}{|l|c|c|c|c|c|c|c|c|}
\hline \multirow{2}{*}{$\begin{array}{l}\text { Severity of } \\
\text { depression }\end{array}$} & \multicolumn{4}{|c|}{ Study group } & \multicolumn{4}{c|}{ Control group } \\
\cline { 2 - 9 } & \multicolumn{2}{|c|}{ Baseline } & At 6 months & \multicolumn{2}{c|}{ Baseline } & \multicolumn{2}{c|}{ At 6 months } \\
\cline { 2 - 9 } & No. & $\%$ & No. & $\%$ & No. & $\%$ & No. & $\%$ \\
\hline Normal & 9 & 30.00 & 21 & 70.00 & 10 & 27.78 & 17 & 47.22 \\
\hline Mild & 18 & 60.00 & 7 & 23.33 & 21 & 58.33 & 15 & 41.67 \\
\hline Severe & 3 & 10.00 & 2 & 6.67 & 5 & 13.89 & 4 & 11.11 \\
\hline Average $\pm S D$ & \multicolumn{3}{|c|}{$\mathbf{1 2 . 8 3} \pm 5.02$} & $8.90 \pm 5.03$ & $13.39 \pm 5.20$ & $12.03 \pm 5.70$ \\
\hline ES & \multicolumn{4}{|c|}{$\mathbf{0 . 7 8}$} & \multicolumn{6}{c|}{$\mathbf{0 . 2 6}$} \\
\hline
\end{tabular}




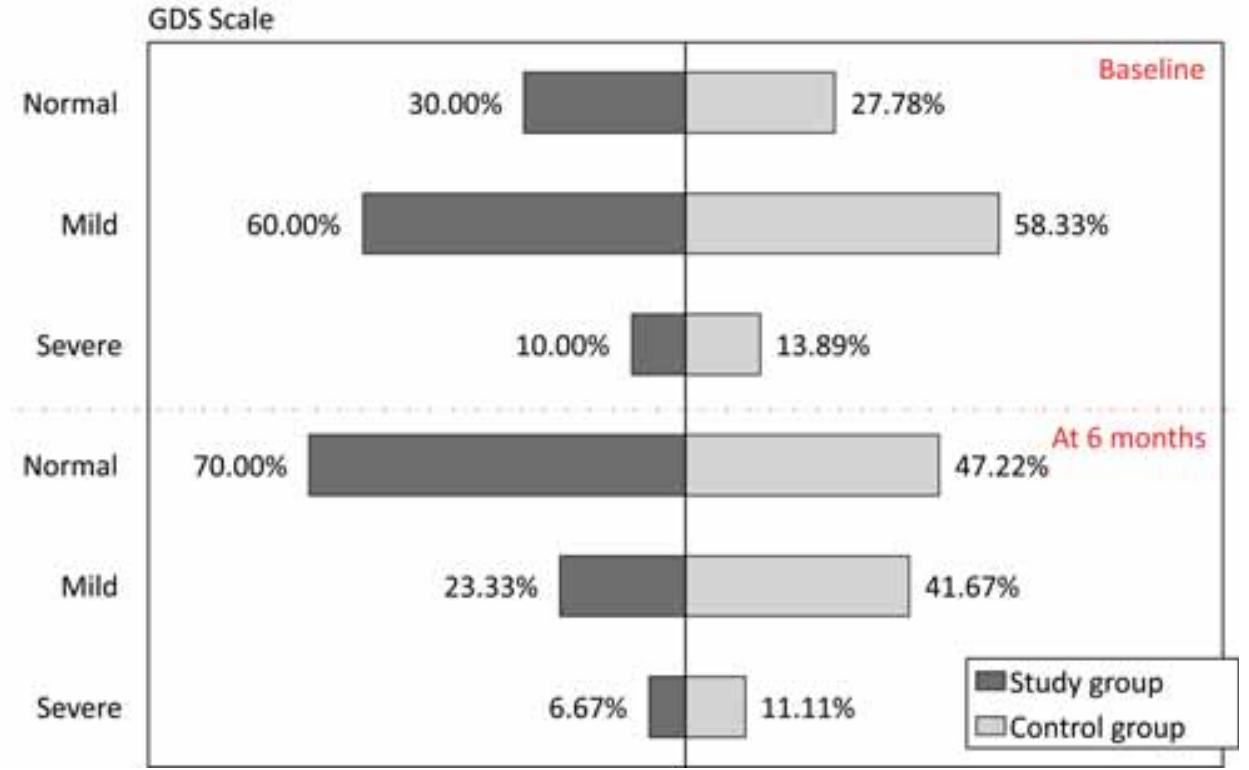

FIGURE 4. Evolution of geriatric depression

\section{Perception of anxiety}

Evolution of the values obtained by measuring the anxiety level for the two groups is presented in Table 5 and Figure 5 below:

TABLE 5. Evolution of anxiety - Hamilton scale

\begin{tabular}{|l|c|c|c|c|c|c|c|c|}
\hline \multirow{2}{*}{} & \multicolumn{4}{|c|}{ Study group } & \multicolumn{4}{c|}{ Control group } \\
\cline { 2 - 10 } & \multicolumn{2}{|c|}{ Baseline } & \multicolumn{2}{|c|}{$\begin{array}{c}\text { At } 6 \\
\text { months }\end{array}$} & \multicolumn{2}{c|}{ Baseline } & \multicolumn{2}{c|}{ At 6 months } \\
\cline { 2 - 9 } & No & $\%$ & No & $\%$ & No & $\%$ & No & $\%$ \\
\hline Low anxiety & 10 & 33.33 & 18 & 60.00 & 11 & 30.56 & 13 & 36.11 \\
\hline $\begin{array}{l}\text { Moderate } \\
\text { anxiety }\end{array}$ & 14 & 46.67 & 9 & 30.00 & 17 & 47.22 & 17 & 47.22 \\
\hline $\begin{array}{l}\text { Anxiety with } \\
\text { worrying } \\
\text { poten al }\end{array}$ & 6 & 20.00 & 3 & 10.00 & 8 & 22.22 & 6 & 16.67 \\
\hline Average $\pm S D$ & $23.27 \pm 8.50$ & $19.20 \pm 7.73$ & $23.97 \pm 7.55$ & $21.92 \pm 8.53$ \\
\hline ES & \multicolumn{4}{|c|}{$\mathbf{0 . 4 8}$} & \multicolumn{5}{c|}{$\mathbf{0 . 2 7}$} \\
\hline
\end{tabular}

We can notice that the severity of anxiety assessed using the Hamilton scale is mild, being initially present in $33.33 \%$ of the patients from the study group and $36.11 \%$ of the patients in the control group ( $\mathrm{p}=0.8128)$. We found out that $16.67 \%$ of the patients in the study group had severe anxiety, compared to $11.11 \%$ of the patients in the control group $(\mathrm{p}=0.5154)$. Regarding anxiety evaluated at 6 months follow-up, it was observed that $40.00 \%$ of the patients in the study group suffered from mild anxiety, the results being similar for the control group, respectively $41.67 \%(\mathrm{p}=0.8915)$. After the same period of time, $13.33 \%$ of the patients from the study group, respectively $11.11 \%$ of the patients from the control group were rated as suf-

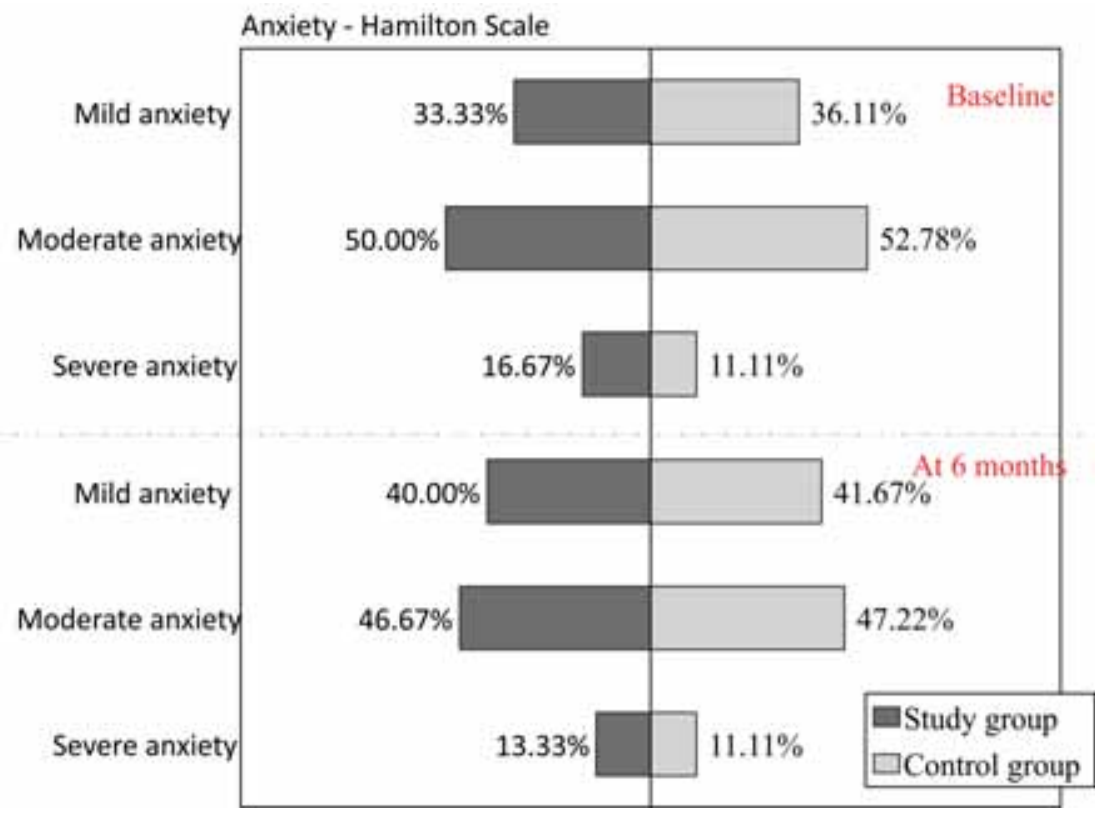

Figure 5. Evolution of anxiety - Hamilton scale 
fering from severe anxiety according to the Hamilton Scale $(\mathrm{p}=0.7848)$.

It was noted that in the Study group, the Hamilton score decreased in 6 months from 19.73 to $18.10(\mathrm{p}=0.0526)$ and in the Control group from 19.69 to $19.00(p=0.3833)$. The effect of treatment on anxiety was 2.3 times higher in the Study group versus the Control group (i.e. $\mathrm{ES}=0.46, \mathrm{ES}=0.20$, respectively).

Table 6 and Chart 6 below show the results calculated for Beck Anxiety Scale (BAI) scores.

TABLE 6. Evolution of anxiety - Beck anxiety inventory

\begin{tabular}{|c|c|c|c|c|c|c|c|c|}
\hline & \multicolumn{4}{|c|}{ Study group } & \multicolumn{4}{|c|}{ Control group } \\
\hline & \multicolumn{2}{|c|}{ Baseline } & \multicolumn{2}{|c|}{$\begin{array}{c}\text { At } 6 \\
\text { months }\end{array}$} & \multicolumn{2}{|c|}{ Baseline } & \multicolumn{2}{|c|}{ At 6 months } \\
\hline & No. & $\%$ & No. & $\%$ & No. & $\%$ & No. & $\%$ \\
\hline Mild anxiety & 10 & 33.33 & 12 & 40.00 & 13 & 36.11 & 15 & 41.67 \\
\hline $\begin{array}{l}\text { Moderate } \\
\text { anxiety }\end{array}$ & 15 & 50.00 & 14 & 46.67 & 19 & 52.78 & 17 & 47.22 \\
\hline \begin{tabular}{|l} 
Severe \\
anxiety
\end{tabular} & 5 & 16.67 & 4 & 13.33 & 4 & 11.11 & 4 & 11.11 \\
\hline Average \pm SD & \multicolumn{2}{|c|}{$19.73 \pm 3.53$} & \multicolumn{2}{|c|}{$18.10 \pm 2.81$} & 19.6 & $9 \pm 3.43$ & \multicolumn{2}{|c|}{$19.00 \pm 3.24$} \\
\hline ES & \multicolumn{4}{|c|}{0.46} & \multicolumn{4}{|c|}{0.20} \\
\hline
\end{tabular}

Initially, as assessed according to the Beck Anxiety Inventory scale, anxiety was rated as low in $33.33 \%$ of the patients in the study group and $30.56 \%$ of the patients in the control group $(\mathrm{p}=0.8113)$ and as worrying potential in $20.00 \%$ of the patients in the study group and $22.22 \%$ of patients in the control group $(\mathrm{p}=0.8274)$. After 6 months the anxiety was low at $60.00 \%$ of patients in the Study group and $36.11 \%$ of patients included in the Control group, respectively $(p=0.0547)$, while the anxiety with worrying potential was present in $10.00 \%$ of the patients in the Study group and $16.67 \%$ of patients included in the Control group ( $p$ $=0.4353$ ), respectively.

In the Study group, mean Beck anxiety inventory scores decreased in 6 months from 23.27 to 19.20 (p $=0.0572)$ and in the Control group from 23.97 to $21.92(p=0.2840)$ and the effect of treatment on anxiety was 1.8 times higher in the Study group than in the Control group ( $\mathrm{ES}=0.48, \mathrm{ES}=0.27$ ).

The cause of depression is considered to be a biochemical imbalance in the brain. Studies on identical twins indicate that genetic factors contribute $30-42 \%$ to variations in the symptoms of anxiety and depression. In other words, under stressful conditions, vulnerable patients will become anxious and depressed just as other patients are prone to diabetes or high blood pressure. However, there are also cases where biochemical changes in the brain arise without a specific cause. According to the World Health Organization, since 2001 it has been estimated that one in four people is prone to develop neurological or mental health problems throughout their lives. Moreover, about 350 million people worldwide suffer from depression and this is also the main mental health problem encountered in adolescents and young people, according to the same World Health Organization (5).

A series of permanent disorders associated with coordination and movement, attention and especially memory can cause stroke and can also generate depression symptoms, all of which have repercussions on patient recovery.

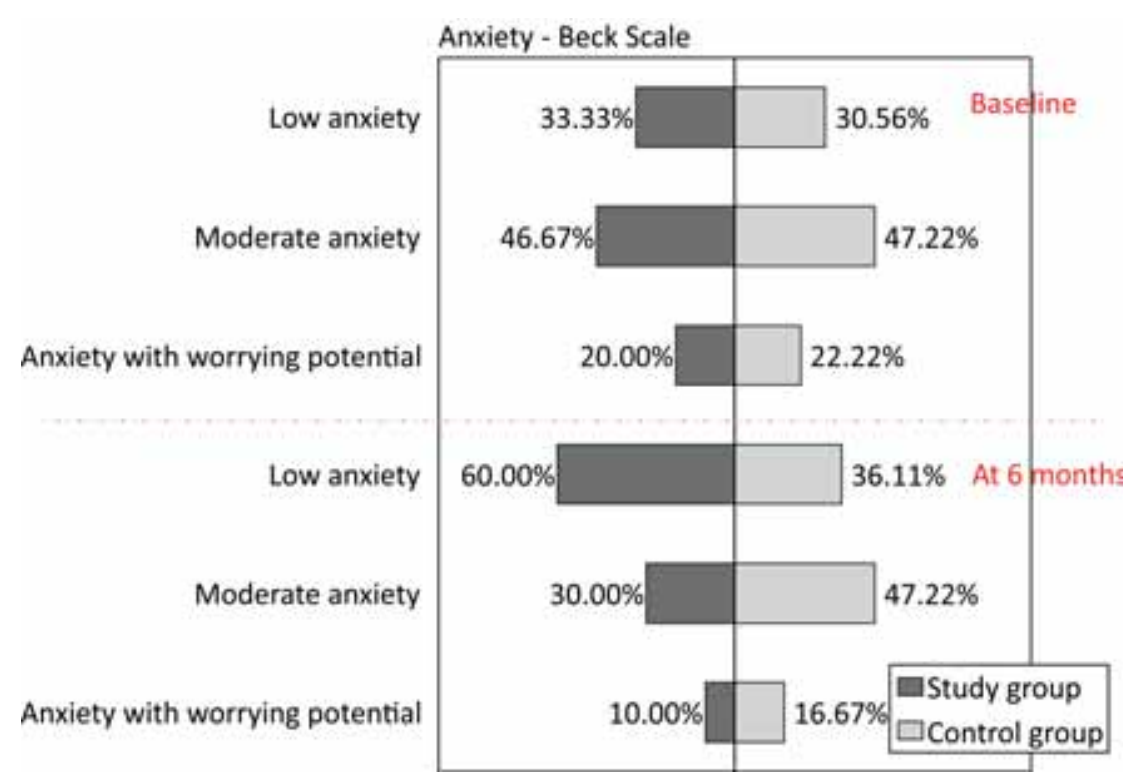

FIGURE 6. Evolution of anxietyBeck anxiety inventory 
It is estimated that $30-40 \%$ of stroke survivors develop a certain level of functional dependence, which then requires assistance in performing basic Activities of Daily Living: (ADLs) (6).

In the first place in the prevalence of mental illness, anxiety disorder are $17 \%$ and the risk of being present at any time of life increases to $25 \%$, most frequently in women than in men in a ratio of 2:1 (Kessler) (7). The causes of anxiety disorders are not fully known, but environmental, biological and psychosocial factors are involved. However, in the emergence of these disorders there is a certain genetic predisposition. On the other hand, comorbidity with other psychiatric disorders such as the presence of mood disorders is very common (8).

Computer programs have been proven to be an instrument with many advantages, including a great potential in aiding cognitive recovery (Lynch, 2002, Bracy, 1983) (9).

On the other hand, it was observed that as the patients surveyed in the Study group adapted to the new therapy by multisensory stimulation with virtual reality, the evolution of the treatment had favourable results, the anxiety being diminished significantly even after the 6 months which was confirmed not only by the statistical data but also by the discussions with the patients and after an assessment of their general health condition in comparison with the patients included in the Control group whose symptoms of anxiety and depression stagnated.

The need for medical recovery addresses is essential due to lesions and surgery and seeks to improve communication, muscle strength, coordination and mobility and these recovery treatments can lead to a substantial improvement in the patient's ability to carry out their activities of daily and improve the quality of life (10).

Patients have feelings and moments when they feel positive emotions, for example: joy, compassion and love and this happens surprisingly even when stress is intense and things go wrong. However, many of these positive moments help patients to reduce the harmful effects that can occur especially when the body is stressed for a longer timeframe (11). Medical recovery has been characterized as a suitable tool for recovering cognitive functions of patients due to the fact that it allows for the setting of a contained and comprehensive environment. Moreover, the presence of a virtual environment can allow systematic evaluation of patients because all tasks in the virtual environment are performed and are related to activities of daily living (12).

\section{CONCLUSIONS}

The results have demonstrated that the use of multi-sensory stimulation therapy with virtual reality in a virtual environment can contribute to the medical recovery of patients with stroke.

The therapy used has promoted positive effects in the recovery of the following functions: anxiety disorder, fear, insomnia, behaviour, cognitive symptoms including memory and concentration, sensory somatic symptoms, depression, gastrointestinal, cardiovascular, genitourinary and vegetative symptoms, and muscle tension. The positive effects in the functional questionnaires used in the study have led to major improvements in the activities of daily living of patients.

Early observation and evaluation of depressive symptoms following a stroke are essential as they diminish the negative consequences on the recovery of patients with stroke.

The role of multi-sensory stimulation therapy with virtual reality in recovering patients included in the Study group had a motivational effect, being interesting and interactive through the games it put forward.

Our study demonstrates that medical recovery through multi-sensory stimulation with virtual reality is an effective, cheap and convenient therapy for hemiparesis patients similar to the results published by other authors (13).

\section{REFERENCES}

1. Jakob Oblak, Imre Cikajlo, and Zlatko Matjačić, Universal haptic drive: A robot for arm and wrist rehabilitation, http://www.ir-rs.si/f/ docs/Znanstveni_clanki/oblak_2009tnsrepreprint.pdf, pg. 1.

2. https://semneletimpului.ro/religie/crestinism/crestini/ce-ar-trebui-sastie-un-crestin-despre-depresie-si-anxietate.html

3. José Eduardo Pompeu, Thais Helena Alonso, Igor Bordello Masson, Sandra Maria Alvarenga Anti Pompeu, Camila Torriani-Pasin, Os efeitos da realidade virtual na reabilitação do acidente vascular encefálico: Uma revisão sistemática The effects of virtual reality on stroke rehabilitation: $\mathrm{A}$ systematic review, Motricidade 2014, vol. 10, n. 4, pp. 111-122, pg.112. 
4. Pedro Roy Millán y Belén Garzón Ruiz, Tratamiento de los trastornos afectivos y conductuales en el envejecimiento, Olga Bruna, Teresa Roig, Miguel Puyuelo, Carme Junque y Ángel Ruano, Rehabilitación neuropsicológica, Intervención y práctica clínica, 2011 Elsevier España, S.L., pg. 347.

5. https://semneletimpului.ro/social/psihologie/depresie/de-la-intunericla-speranta.html

6. Health technology assessment of chronic disease self-management support interventions

7. Stroke, Health Information and Quality Authority Dublin Regional Office, Health Information and Quality Authority 2013, pg. 139

8. Américo Reyes-Ticas, Trastornos de ansiedad Guia practica para diagnostico y tratamiento, http://www.bvs.hn/Honduras/pdf/ TrastornoAnsiedad.pdf, pg. 33.

9. Guía de Práctica Clínica para el Manejo de Pacientes con Trastornos de Ansiedad en Atención Primaria, http://www.guiasalud.es/GPC/ GPC_430_Ansiedad_Lain_Entr_compl.pdf, pg 32 .

10. Rocío Sánchez-Carrión, Almudena Gómez Pulido, Alberto GarcíaMolina, Pablo Rodríguez Rajo y Teresa Roig Rovira, Tecnologías aplicadas a la rehabilitación neuropsicológica, Olga Bruna, Teresa Roig, Miguel Puyuelo, Carme Junque y Ángel Ruano, Rehabilitación neuropsicológica, Intervención y práctica clínica, 2011 Elsevier España, S.L., pg. 132.
11. Steffanie Goodman MPH, Michael Rabow MD, Susan Folkman PhD, Orientación para el cuidado continuo Manual para los encargados del cuidado continuo de pacientes con enfermedades graves, 2009 the Regents of the University of California, Capitulo 3 / Página 3.5.

12. Steffanie Goodman MPH, Michael Rabow MD, Susan Folkman PhD, Orientación para el cuidado continuo Manual para los encargados del cuidado continuo de pacientes con enfermedades graves, 2009 the Regents of the University of California, Capitulo 8 / Página 8.2

13. Alicja Banaś, Marian Majchrzycki, Wanda Stryła, Mateusz Kruszyński, Sylwia Piotrowska Technologie wirtualnej rzeczywistości w procesie usprawniania funkcji chodu oraz równowagi u osób po przebytym udarze mózgu, Diagnostyka i usprawnianie pacjentów z dysfunkcjami narządów ruchu, Copyright by Uniwersytet Medyczny im. Karola Marcinkowskiego w Poznaniu, Poznań 2013, pg 115.

14. Alicja Banaś, Marian Majchrzycki, Wanda Stryła, Mateusz Kruszyński, Sylwia Piotrowska Technologie wirtualnej rzeczywistości w procesie usprawniania funkcji chodu oraz równowagi u osób po przebytym udarze mózgu, Marian Majchrzycki, Magdalena Łańczak-Trzaskowska, Ewa Gajewska, Diagnostyka i usprawnianie pacjentów z dysfunkcjami narządów ruchu, Copyright by Uniwersytet Medyczny im. Karola Marcinkowskiego w Poznaniu, Poznań 2013, pg 115. 